\title{
The Morphological Analysis of Zulu Clan Names
}

\author{
Celani Lucky Zwane \\ Correspondence: Celani Lucky Zwane, Department of African Languages, University of South, Africa, Pretoria, \\ 0002, South Africa.
}

Received: Dec. 18, 2019

Accepted: June 25, 2020

Online Published: Sep. 24, 2020

doi:10.5430/elr.v9n3p36

URL: https://doi.org/10.5430/elr.v9n3p36

\begin{abstract}
The focus of this paper is that some scholars and people are not aware of the morphological structure of Zulu clan names. The clan names in themselves cipher secreted information that would be a story, history, a very long story perhaps which talks about the people of that clan, it could be Kings, famous people or a whole family. The main aim of the paper is to make people aware of the morphological structure of Zulu clan names. Research findings indicate that there is morphological structure in Zulu clan names that most scholars and Zulu people are not aware of. This study found that the structure of a clan name and its meaning are related. An example of such a clan name is Hlabangane (slaughter four); [Hlaba (slaughter) + nga (per) + -ne (four)], which indicates that the clan name giver saw people of this clan slaughtering four cows when they had traditional ceremonies. However, through the use of this clan name, the clan name giver appears as a person who experienced or observed Hlabangane people repeating the same procedure several times and no one disagreed with him because it was a fact. The researcher have used document analysis and in depth personal interviews to gather data for this paper.
\end{abstract}

Keywords: morphology, Zulu clan names, Morphemes

\section{Introduction}

Clan naming practices among the Zulu form an integral part of their culture and tradition: the clan naming process is a social activity. Each Zulu clan name represents a compact history of how the Zulu perceive life and interact with the environment on a daily basis. These clan names reflect the Zulu inner being and their views about life; experiences, their Heroes and Kings. Koopman (1990:333) states that "Zulu surnames, or clan names, as I prefer to call them, differ from European surnames in that they have a potential for morphological change". It is the morphological structure of Zulu clan names that this article deals with. Morphologically speaking, when clan names are constructed from different word categories, it becomes easier for the clan name giver to communicate his/her feelings to the entire community, minimising possible friction. Zulu clan names, like other African clan names, are derived from word categories such as nouns, verbs, qualificatives, interrogatives, compounds and pronouns. These terms will be discussed in detail below.

The objective of this article is to analyze the morphology of the Zulu clan names in order to gain a deeper understanding of the patterns that are followed in their formation. The relationship between morphology and meaning in these Zulu clan names will be pointed out.

\section{Literature Review}

Zulu clan names specifically fall within the larger field of orality, which has been researched in extensive detail. The study of clan names specifically has received some attention. Many of Nguni (Xhosa, Swati and Ndebele) clan names have historical connections with Zulu clan names and families, having moved to different places because of good reasons. Zulu clan names also fall under Nguni clan names as there are four nations under Nguni which is Xhosa, Swati, Ndebele and Zulu.

The studies of Mzolo (1977), Kamera (1999), Turner (1995,) Ndawo (1939), Damane and Sanders (1974), Fortune (1976), Msimang (1991, 1975) and Zwane (2015) were consulted. Turner (1998) states that clan names serve as useful to distinguish one particular person from another in the community or society at large.

\section{Methodology}

Qualitative and desktop methods were used to collect data. Published material and not published material that is found in libraries was used to collect data. Interviews were used to collect data. Data were collected from 50 
participants residing at Esdakeni, Number 1 and Number 2 found under the Kwahlathi Tribal Authority at Ladysmith which is one of the well-known towns found in KwaZulu-Natal. Qualitative and desktop methods were used to collect data.

Babbie (1998:290) says:

A qualitative interview is an interaction between an interviewer and a respondent in which the interviewer has a general plan of inquiry but not a specific set of questions that must be asked in particular order. A qualitative interview is essentially a conversation in which interviewer establishes a general direction for the conversation and pursues specific topics raised by the respondent. Ideally the respondent does most of the talking.

Qualitative research has a person who asks questions and someone or some people who answer open and closed questions. The interview takes place between two or more people. Interviewee can be one or more people. Usually in a qualitative interview the person who does a lot of talking is the interviewee. This research was conducted qualitatively by analysis, description and interpretation of the data collected.

\section{Theoretical Framework}

This article is based on two theoretical frameworks, the orality (Ong, 1982) and oral style (Jousse 1990). These two theories are used because they link with the topic of the article. Orality and oral style are both based on oral communication and Zulu clan names are part of oral literature.

\subsection{Orality}

Walter Ong is the author of the theory of orality. Zulu clan names are still largely oral. Oral means they are communicated by word of mouth from one generation to the next. Zulu clan names are essentially oral, they depend on performance for their existence.

Finnegan (1982:2) states that:

Oral literature is by definition dependent on a performer who formulates it in words on a specific occasion - there is no other way in which it can be realized as a literary product.

Kaschula (1993: vii) corrected the wrong perception that was suggested by some people, saying oral literature is old fashioned when he says that.

Oral literature is essentially about the past, the present, and the future. It represents a window into the world view of a particular society, its values and beliefs.

It is a fact that the values and beliefs of the Zulu clan names have the important information that was important in the past, important in present time and important in the future.

Okpewho (1992: 3) defines oral literature as follows:

It simply means "literature delivered by word of mouth".

The given characteristics apply to the Zulu clan names in terms of the following: they are transmitted from generation to generation; they are delivered by word of mouth; they are recited by performers on various occasions; they are about the past, the present and the future life of the Zulu; and they are the vehicle that conveys the Zulu's history, values and beliefs, (Mzolo, 1977).

\subsection{Oral Style}

Marcel Jousse is the author of the theory of oral style. Oral style focuses on oral communication. As Zulu clan names are orally communicated, the oral style theory is relevant to this article.

Akiva and Odaga (1982:1) say:

Oral literature is a spoken word, acted (performed) art whose media, like that of written literature, is words. 
Oral art is an oral word. Communication, as well as in writing, occurs in oral words.

Jousse (1990:25) suggests that:

Human behaviour is observable from two standpoints; those microscopic and macroscopic observers. The microscopic observer is the performer observer while the macroscopic observer is the audience observer.

Personal behavior is viewed from both sides; small observer great observer. A small observer is an acting observer while a great observer is a watching observer.

Nkosi and Msomi (1992:1) say that when people are communicating, talking, think about each other, this is a sign of understanding that they are talking about. Understanding is created by that they speak the same language.

This theory of Jousse (1990) developed the basis for this article, since Jousse personally acquired knowledge and skills by oral art. By considering this work the knowledge of Zulu clan names from the oldest generation has passed through to the new generation through oral communication.

In this article the researcher discussed clan names derived from different word categories. Examples of clan names derived from the verb stem; clan names derived from compounds; clan names that are derived from a noun and an adjective; clan names that are derived from a verb and an adjective; clan names derived from verb and a pronoun; clan names derived from a noun and an adverb; clan names derived from a verb and a verb; clan names derived from a noun and a noun; clan names derived from a noun and a pronoun; clan names derived from a noun and an adjective; clan names derived from a noun and a relative was the subject of discussion.

\section{Morphology}

Morphology is defined as the study of the structure of words and words formation. Nida (1976), Kosch (1997) and Haspelmath (2002) concur that it is the study of the internal structure of words and that it also shows how morphemes are systematically put together to make the meaning of a word. Morphology is that significant piece of grammar or linguistics that specializes in the study of the anatomy of word categories found in all languages of the universe, (Zungu, 1999:76). Morphology deals with how dissimilar word categories are created, i.e. how morphemes are positioned during the formation of a word. If the morphemes are not positioned correctly, that particular word will not have clear meaning in that specific language. Clan names carry history of families and there is a lot of information that is found on them, (Haspelmath, 2002).

A Zulu prefix um(u)- (class 1), for example, cannot be broken down further without losing its meaning entirely. A root morpheme is that significant piece of a word which carries the crucial meaning. Zulu derive their clan names from different word categories. Zulu clan names are morphologically rich and reflect Zulu culture, as it is reflected in the language. Bonvillain (1997:1) suggests this about the connection between morphology (word structure) and culture (language use):

Language is an integral part of human behaviour. It is the primary means of interaction between people. Speakers use language to convey their thoughts, feelings, intensions and desires. Language is enriched by the uses that people make of it. These uses and the meanings transmitted are situational, social and cultural.

It is not easy to separate the naming process from the use of language as a means of communication, especially among Zulu people. Naming is a branch of culture and language. Whenever morphemes are put together to produce a new word, this new word is carefully coined to carry the message transmitted by the clan name giver. The experiences and aims of the clan name giver are immediately revealed through the clan. Zulu clan names are formed from bound morphemes such as prefixes and suffixes.

\section{Results and Discussion}

Results and discussion and base on different clan names that were researched. Clan names are the roots of different nations. They are used in daily lives. Clan names are filled with history, each clan name is carrying an important history of some people. They are used in different cultural ceremonies. Some Zulu men use clan names when they greet each other. Researchers and scholars need to research and pay attention on different clan names as they are very 
important in societies and have important information. When the researches are done with clan names, next generations will be able to get important information about their clan names and when the researches are not done, the important information will die about clan names.

\subsection{Clan Names Derived From the Verb Stem}

Some of Zulu clan names are derived from the verb stem. Taljaard and Bosch (1998:5) say the following about the isiZulu verb:

The isiZulu verb has one important characteristic, viz. that it consists of a root or a radical which carries its basic meaning. This root, by itself, cannot be used in the language. Only after certain prefixes and suffixes have been have been added to this root, does it acquire functional value.

There is a single significant characteristic that is found on a verb. The Zulu verb root carries the meaning of the word that is important. Prefixes and suffixes are added to a root to get full clear meaning of the word.

Poulos and Msimang (1998:169) say the following about the isiZulu verb:

A verb in Zulu consists of a number of morphemes that are in a sense "put together" - these may be, for example, a subject concord which refers to the subject of the verb; a tense marker or formative which expresses a particular tense; an object concord which refers to some or other object; a verb root which expresses the basic meaning of the action or state, and a suffix which comes at the end and which sometimes gives us some indication of the tense of the verb. Some of the above morphemes do not always occur in a verb, for example, as will be seen later, a subject concord is not used in imperative verbs, and the use of an object concord is optional in many cases. The verb root, on the other hand, is an obligatory part of each and every verb.

Zulu verb stems carry the meaning of the word. The verb stem has the root and verb suffix. The significant element of the verb stem is the root, because the meaning of the verb stem is given by the root. The root is the key part to which other parts of the word are added (Coates, 1999:27).

Kosch et al. (2004:43) suggest the following about the root:

The root or stem forms the core of the derived word. In the African languages its meaning is often only an approximate one, which is narrowed down to a specific meaning once it is combined with the other constituent(s) of the word.

The Zulus depict many of their clan names from this category. Generally, they are the mirrors of the social issues among the Zulus. In this part the focus was on the form of these clans. In terms of their structure, they are created from a verb root plus a suffix. A root carries the important meaning of the verb. Poulos (1990:153) says:

The verb root represents the "core" of the verb - the part that expresses the basic meaning of the verb.

A root can thus be understood as the foundation on which a word is formed. Structurally, clan names under this category are formed from the verb root, the terminal and the suffix.

According to Taljaard and Bosch (1998:5):

The different suffixes, also called verbal extensions or verbal derivative suffixes, are added to the root in order to enlarge the applicability of the basic meaning to different contexts. When such a suffix is added to the root, it becomes a verb stem. 
Different suffixes that may be added to a root are -a, -ela, -ile, -isa, -ana and -isana, (Taljaard and Bosch, 1998:5). The suffix -wa also may be added.

Examples of clan names derived from the verb stem are given below:

\subsubsection{Duma (Be famous)}

This is derived from the root -dum-, with the basic meaning of "be famous" plus the suffix -a. The root -dum- also means thunder or tasteless or notorious or well known or lack flavour. The suffix -a is found in all positive verb stems. This clan name of Duma started when people of this clan were famous because they were good in wars and very stubborn. All surrounding people were talking about them and that is why the clan name giver said, "you are famous and from today your clan name is Duma". When Duma people are bestowed, the clan name-giver sends a warning message to people that Duma people are famous because they were very dangerous, based on his experience or observation, (Mzolo, 1977).

Dum- $($ root $)+-$ a (suffix $)=$ Duma $($ verb $)$

\subsubsection{Mbatha (Cover Your Body/Get Dressed/Cloth)}

This is formed from the root -mbath- (dress), plus the suffix -a. The root -mbath-still carries the basic meaning of cover or cloth. The suffix -a is found in all positive verb stems. This clan name was given to the people of this clan as they were killing animals that were not killable easily and wear skin of those animals. It appears in their clan praise names where they say in Sithole (1982:57) "Nina enabamba inyamazane engabambekiyo" (You who catched uncatchable animal); "Neza koMkhulu senembeth' isikhumba sayo" (You came to the Greater and covering your body with its skin). Through this clan, people are reminded that people of Mbatha can catch uncatchable animal, kill it and wear its skin, (Mzolo, 1977).

- Mbath- $($ root $)+-$ a $($ suffix $)=$ Mbatha $($ verb $)$

\subsubsection{Zuma (Fight Unaware)}

This clan name is formed from the root -zum- (unaware), plus the suffix -a. The root -zum-also means take by surprise or surprise. The suffix -a is found in all positive verb stems. This clan name was given to the people of Zuma because they were attacking their enemies while they were not aware of that they are coming. This type of clan name is categorized as warning clan name, as Zuma enemies were warned by the clan name giver based on his experience that they should be careful as they can be attacked even if they are not aware of at anytime. This is how Zulu people warn one another when there is a need, it is seen on clan names or clan praises.

-Zum- (root) + -a (suffix) = Zuma (verb)

\subsubsection{Hlela (Plan/Arrange/Put in Order/Adjust/Settle)}

This name is formed from the root -hlel- meaning "Plan" plus the suffix -a. The root -hlel- also means arrange or put in order or adjust or settle. The suffix -a is found in all positive verb stems. Through this clan name people are made aware of that people of Hlela like to plan things (like going to wars or when they had ceremonies) before they take actions. Hlela people were very organized. When people of this clan were planning for wars, they were planning which methods will assist them to defeat their enemies, they were searching weaknesses of enemies before they attack them. It is a Zulu nation belief that people do not simply attack enemies, but they plan before, so that they will use weaknesses of their enemies and bring effective strategies to defeat them in wars, (Malibe, 2009).

-Hlel- $($ root $)+-$ a (suffix) $=$ Hlela $($ verb $)$

\subsubsection{Hlabisa (Cause to Slaughter)}

This type of clan name is formed from the root -hlab- meaning "slaughter", plus the suffix -isa. The -hlab- also means stab. -Isa is the suffix, denoting the cause, indicating, 'cause to do', 'help to do', (Doke, Malcolm, Sikakana and Vilakazi, 2014: 743). The history behind this clan name is that the people of this clan had lot of cows and were helping neighbours who did not have enough cows by giving them some to slaughter when they had their traditional ceremonies. From that time people said you are Hlabisa because you help us to slaughter if we do not have sufficient cows, (Malibe, 2009).

-Hlab- $($ root $)+$-isa $($ suffix $)=$ Hlabisa $($ verb $)$

\subsubsection{Goba (Bow Down)}

This name is formed from the root -gob- meaning "bow down" plus the suffix -a. The root -gob-also means bend or 
bend over or curve or stoop. The suffix -a is found in all positive verb stems. Through this clan name people are made aware of that people of Goba when their enemies have seen that they are defeated, they were bowing down which was showing that they accept that they are defeated, and after bowing down they were not killed. It also means the Goba people were bending stubbornness of their enemies in wars by defeating them. It is a Zulu belief that when an enemy is bowing down and apologizing you stop fighting him, because he symbolizes that he is defeated, (Sikhosana, 1997).

- Gob- $($ root $)+-$ a (suffix $)=$ Goba $($ verb $)$

\subsubsection{Hlongwa (Be Detected)}

This name is formed from the root -hlong- meaning "detect" plus the suffix -wa. The root -hlong- also means find. -Wa is the suffix, denoting the pass, (Doke, Malcolm, Sikakana and Vilakazi, 2014: 1199). Amahlongwa means species of long grass. Hlongwa means be detected or be found. Through this clan name people were made aware that people of clan Hlongwa were detected in a place where there is was species of long grass. This clan shows that Zulu clans also talk about the places of where people of the particular clan were staying, (Malibe, 2009).

-Hlong- (root) + -wa (suffix) = Hlongwa (verb)

\subsubsection{Zindela (Be Firmly Based for)}

This name is formed from the root -zind- meaning "be firmly based" plus the suffix -ela. The root -zind- also means hold back for. -Ela is the suffix, denoting the applied, indicating 'do for, on behalf of, towards', (Doke, Malcolm, Sikakana and Vilakazi, 2014: 585). Through this clan name people are made aware that people of Zindela were taking time to move to another place, they were pushed by very big reasons only. The clan name giver said they are the people of Zindela which means they were not moving easily to where they were staying. When they were moved by wars it was only more armed, trained and powerful enemies, (Sikhosana, 1997).

-Zind- (root) + -ela (suffix) $=$ Zindela $($ verb)

\subsubsection{Thembela (Trust in)}

This name is formed from the root -themb- meaning "trust in" plus the suffix -ela. The root -themb- also means believe in or rely on or expect on. -Ela is the suffix, denoting the applied, indicating 'do for, on behalf of, towards', (Doke, Malcolm, Sikakana and Vilakazi, 2014: 585). Through this clan name people are made aware that people of clan name Thembela were not strong in wars as they were relying on their friends for support during wars. That is why the clan name giver said you are Thembela (the people who rely others for protection), (Sikhosana, 1997).

-Themb- (root) + -ela (suffix) $=$ Thembela (verb)

\subsubsection{Thwala (Carry on Head/Shoulders)}

This name is formed from the root -thwal- meaning "carry" plus the suffix -a. The root -thwal- also means kidnap or load or transport. The suffix -a is found in all positive verb stems. Through this clan name people are informed that people of Thwala have power. There is a section on their clan praises where it says "Nina beqhawe elathwala inkomo" (You of a warrior who carried a cow on his shoulders." From the clan name giver 's experience it shows that he seen Thwala warrior strength and after that he believed that people of Thwala have lot of power. The warrior of Thwala who carried cow had lot of power, it was said that the cow was alive which also shows that he had lot of power as the cow is more heavier when it's alive and it's not easy to carry than when it is slaughtered, (Mzolo, 1977).

- Thwal- $($ root $)+-$ a $($ suffix $)=$ Thwala $($ verb $)$

\subsubsection{Yengwa (Be Enticed)}

This name is formed from the root -yeng- meaning "entice" plus the suffix -wa. The root -yengw- also means be decoyed or allure or seduce or beguile. -Wa is the suffix, denoting the pass, (Doke, Malcolm, Sikakana and Vilakazi, 2014: 1199). Through this clan name people are told that people of Yengwa are enticeable easily. The clan name giver of this clan experienced or observed that people were enticing Yengwa people and they were believing them. It was said that Yengwa people were believing people easily that is why they were defeated easily on wars and their cows were stolen as they were trusting even wrong people.

-Yeng- (root) + -wa (suffix) = Yengwa (verb)

\subsubsection{Chiliza (Push Aside)}

This name is formed from the root chiliz- meaning "push aside" plus the suffix -a. The root -chiliz- also means push away. The suffix -a is found in all positive verb stems. Through this clan name people are notified that people of 
Chiliza had power as they were killing people in wars like they were pushing them away, they had incredible skills. People of Chiliza were trained to defeat enemies without having lot of stress in wars, (Malibe, 2009).

-Chiliz- (root) + -a ( suffix) $=$ Chiliza (verb)

\subsubsection{Lamula (Bhengu) (Make Peace)}

This name is formed from the root -lamul- meaning "make peace" plus the suffix -a. The root -lamul- also means stop war, separate, e.g. separate fighters. The suffix -a is found in all positive verb stems. Through this clan name people are made aware that people of Lamula were making peace between fighting or contending families as there were the people who did not like fights or wars. The clan name giver said they are the people of Lamula which means they were making peace. Wherever they were moving to, they wanted to see peace, (Sikhosana, 1997).

-Lamul- (root) + -a (suffix) = Lamula (verb)

\subsubsection{Khumbuza (Cele) (Remind)}

This name is formed from the root -khumbuz- meaning "remind" plus the suffix -a. The root -khumbuz- also means cause to remember. The suffix -a is found in all positive verb stems. Through this clan name people are made aware that people of Khumbuza were reminding their enemies when they attack them about what they did to them in the past, when they pay revenge. The clan name giver said you are the people of Khumbuza which means they were not forgetting easily. They were able to keep grudges for a very long time, (Malibe, 2009).

-Khumbuz- (root) + -a (suffix) = Khumbuza (verb)

\subsubsection{Biyela (Fence Round)}

This name is formed from the root -biy- meaning "fence" plus the suffix -ela. The root -biy-also means construct a fence for or against. -Ela is the suffix, denoting the applied, indicating 'do for, on behalf of, towards', (Doke, Malcolm, Sikakana and Vilakazi, 2014: 585). Through this clan name people are made aware that people of Biyela had lot of cows, and cows were fencing their yards. The clan name giver said you are the people of Biyela which means they were fencing their kraals with cows, (Mzolo, 1977).

-Biy- $($ root $)+$-ela $($ suffix $)=$ Biyela $($ verb)

\subsection{Clan Names Derived From Compounds}

Compounds are words that are formed from two or more independent word categories, such as a noun and a verb, a noun and a qualificative or a verb and a noun. According to Matthews (1991:15) a compound is a word whose parts may themselves be words in other contexts. Compounding is a procedure by which a compound lexeme is derived from two or more simpler lexemes, (Matthews, 1991). Crystal (1991:70) defines a compound as:

A term used widely in descriptive linguistic studies to refer to a linguistic unit which is composed of elements that function independently in other circumstances.

Compounds are the prototypical concatenation of words to form other words, (Spencer, 1991:309). Kosch (2006:122) concurs with Spencer when he says a compound word is a syntactic mixture of two or more existing words to form a new compound word.

Nkosi, Mashimi, Wilkes and Ntuli (1994:120) state this about compound, when we look for nouns such as Uvumazonke (Accept all), ivelakancane (rare thing), uyisemkhulu (old father or grandfather), etc. We quickly notice that they are made up of different words. The noun that is ivelakancane is made up of a verb stem vela and and the extension -kancane (a bit). The noun uyisemkhulu, it is made up of the noun, parts of speech which are two or more of the two called the amabizongxube (compound noun). Compound nouns can be divided into the following ways. 1. Noun and noun, 2. Noun and pronoun, 3. Noun and adjective, 4. Noun and relative, 5. Noun and possessive, 6. Noun and verb, 7. Verb and Noun, 8. Verb and pronoun, 9. Verb and adverb.

Koopman (1984: 96) concurs with Nkosi et al. when he says "Zulu compound nouns can be divided into those with the structure $(\operatorname{verb}+\mathrm{x})$, where $\mathrm{x}=$ any part of speech, and those with the structure [Other (i.e. non-verb) $+\mathrm{x})$ ]." Compound noun is formed from two or more parts of speech which includes noun, pronoun, and adjective, relative, possessive, verb, and adverb. Zulu compounds are formed from the combination of any word categories, e.g. noun plus pronoun. 


\subsection{Clan Names That Are Derived From a Noun and an Adjective}

Nkosi et al (1994:121) say this noun and an adjective often the first vowel are removed. Most of the compounds in this section refer to the proper nouns or relationships.

Nouns that are derived from a noun and an adjective fall under nouns of class 3, 6 and 9, umu-; ama- and in-. The structure of this type of clan name is as follows: relative concord umu-; ama- and in-. plus the verb stem -thi (tree), -shiya eyebrows, -bele (breast) and -kabi (bull) plus the adjective omkhulu (big), amahle (beautiful), -amade (long) and -ende (tall). An adjective is defined as a word category that qualifies a subject or an object in a sentence.

\subsubsection{Mthimkhulu (Hadebe) (Long Tree)}

The noun umuthi (tree) plus an adjective -khulu (big) are combined to produce the clan name Mthimkhulu (long tree). The noun umuthi (tree) is formed from the class 3 (umu- prefix), plus the verb stem -thi (tree) while omkhulu (big) is formed from the adjectice corncord om- prefix plus the adjective stem -khulu. Umuthi and omkhulu have gone through a phonological process. Umuthi is a noun form class 3 , and omkhulu is the adjective.

Umuthi (noun) + omkhulu (adjective $)=(\mathrm{U}) \mathrm{M}(\mathrm{u})$ thi $(\mathrm{o}) \mathrm{mkhulu}=$ Mthimkhulu (compound noun)

\subsubsection{Nkabinde (Tall Bull)}

The noun inkabi (bull) plus an adjective -ende (tall) are combined to produce the clan name Nkabinde (tall bull). The noun inkabi (bull) is formed from the class 9 (in- prefix), plus the verb stem -nkabi (bull) while ende (tall) is formed from the adjectice concord en- prefix plus the adjective stem -de (tall). Inkabi and ende have gone through a phonological process. Inkabi is a noun form class 9, and ende is the adjective.

Inkabi (noun) + ende $($ adjective $)=(\mathrm{I}) \mathrm{Nkabi}(\mathrm{e})$ nde $=$ Nkabinde $($ compound noun $)$

\subsubsection{Mashiyamahle (Ngcobo) (Beautiful eyebrows)}

The noun amashiya (eyebrows) plus an adjective -amahle (beautiful) are combined to produce the clan name Mashiyamahle (beautiful eyebrows). The noun amashiya (eyebrows) is formed from the class 6 (ama- prefix), plus the verb stem -shiya (eyebrows) while -hle (big) is formed from the adjectice corncord ama- prefix plus the adjective stem -hle. Amashiya and amahle have gone through a phonological process. Amashiya is a noun form class 6, and amahle is the adjective.

Amashiya (noun) + amahle $($ adjective $)=($ A $)$ mashiya $(a)$ mahle $=$ Mashiyamahle (compound noun $)$

\subsubsection{Mabelemade (Manana and Nkabinde) (Long Female Breast)}

The noun amabele (female breast) plus an adjective -amade (long) are combined to produce the clan name Mabelemade (long female breast). The noun amabele (female breast) is formed from the class 6 (ama- prefix), plus the verb stem -mabele (female breast) while -made (long) is formed from the adjectice corncord ama- prefix plus the adjective stem -de. Mabele and made have gone through a phonological process. Amabele is a noun form class 6, and amade is the adjective.

Amabele (noun) + amade $($ adjective $)=($ A $)$ mabele $($ a $)$ made $=$ Mabelemade $($ compound noun $)$

\subsection{Clan Names That Are Derived From a Verb And an Adjective}

Nkosi et al (1994:122) say this verb and an adjective often the first vowel is removed. Most of the compounds in this section refer to the proper nouns or relationships.

\subsubsection{Dlamini (Eat Midday)}

The verb idla (eat) and an adjective -emini (midday) are combined to produce the clan name Dlamini (eat midday). The verb idla (eat), the prefix i- plus the verb stem -dla (eat) gives idla; while emini (midday) is formed from the adjectice corncord -e prefix plus the adjective stem -mini. Idla and emini have gone through a phonological process. Dla is a verb, and emini is the adjective.

Dla $($ verb $)+$ imini $($ adjective $)=$ Dla $(i)$ mini $=$ Dlamini $($ compound noun $)$

\subsection{Clan Names Derived From Verb and A Pronoun}

Nkosi et al (1994:123) say this verb and a pronoun, especially pronouns appear as most part of compounds. Also here the verb prefixed the noun class. 


\subsubsection{Khumalo (Chew This One as Dry as It Is)}

The verb khuma (chew dry food) and a demonstative pronoun lo- (this) are combined to produce the clan name Khumalo (chew this dry food). The verb khuma (chew dry food), while lo- (this) is a pronoun. Khuma and lo have gone through a phonological process.

Khuma (verb) + lo (demonstrative pronoun $)=$ Khumalo $($ compound noun $)$

\subsubsection{Hlabangane (Slaughter Four)}

The verb hlaba (slaughter) + nga (per) + ne (four)], which indicates that the clan name giver saw people of this clan that when they had traditional ceremonies they were slaughtering four cows, (Ntshangase, 2015). However, through the use of this clan, the clan name giver appears as a person who experienced or observed Hlabangane people repeating the same procedure several times and no one disagreed with him because it was a fact. Hlaba is a verb, nga is a conjuction and -ne is a quantitative pronoun.

Hlaba (verb) + nga (per) + -ne (pronoun) $=$ Hlabangane $($ compound noun)

\subsection{Clan Names Derived From a Verb and a Noun}

Most of time the first vowel of the noun is removed, the verb is swifted by the noun class. Nkosi, Mashumi, Wilkes and Ntuli (1994:122) say this about a verb and a noun, usually the first vowel of the noun is deleted, the verb is prompted by the class of the noun.

\subsubsection{Dlangamandla (Depend on Power)}

The verb dla (eat), nga (with) and a noun amandla (power) are combined to produce the clan name Dlangamandla (depend on power). The other meaning of Dlangamandla is eat by using power. The noun amandla (power) is formed from the class 6 (ama- prefix/before vowel stems), plus the root stem -ndla (power) while -dla (eat) is the verb and -nga- (with) is the construction. Dla (eat) + nga (with) (construction) + amandla (power) have gone through a phonological process.

-Dla- $($ verb $)+-$ nga- $($ construction $)+$ amandla $($ noun $)=$ Dlanga $(a)$ mandla $=$ Dlangamandla $($ compound noun $))$

\subsection{Clan Names Derived From a Verb and a Pronoun}

Nkosi et al (1994:123) argue the following about verb and pronoun, it is pronouns especially from which they form part of these compounds. Here the verb is prompted for the class of the noun. It is pronouns that are part of compound nouns. Also here the verb is swifted by the noun class.

\subsubsection{Khumalo (Eat This One Uncooked)}

The verb khuma (eat uncooked) and pronoun lo (this one) are combined to produce the clan name Khumalo (depend on power). The other meaning of Khumalo is a species of thorny tree. The clan name giver, it is said he gave Khumalo people this clan because they had lot of heroes who were winning wars, the way they were fast in wars it was associated with someone who eat uncooked food. It is said some Khumalo people said this clan was given to them because they were staying in a place where there were lot of species of thorny tree. Khuma (eat uncooked) and pronoun lo (this one) (construction) + have gone through a phonological process.

Khuma (verb) + Lo (demonstrative pronoun) $=$ Khumalo (compound noun)

\subsubsection{Buthelezi (Collect These)}

Butha (collect) + lezi (these) are combined to produce the clan name Buthelezi. The other meanings of Butha are recruit or enroll in regiment). It indicates that the clan name giver saw people of this clan after defeating their enemies they were collecting their cattles. Buthelezi clan had powerful army. However, through the use of this clan, the clan name giver appears as a person who experienced or observed Buthelezi people repeating the same procedure several times and no one disagreed with him because it was a fact.

Butha $($ verb $)+$ ilezi $($ demonstrative pronoun $)=$ Buth(a)(i)lezi $=$ Buthelezi $($ compound noun $)$

(a and $\mathrm{i}$ combined to give e). 


\subsection{Clan Names Derived From a Noun and an Adverb}

Also here the verb prefixed the noun class.

\subsubsection{Ngwekazi (Big Leopards)}

The noun izingwe (leopards) + kazi (big) are combined to produce the clan name Ngwekazi. Izingwe is a noun class 10, izin- is a prefix of noun class 10 and root stem -ngwe. The suffix -kazi are used to indicate the femine sex and the augmentative, (Taljaard and Bosch, 1998:144). In this clan -kazi is used to indicate augmentative. It indicates that the clan name giver saw people of this clan that when they were fighting like leopards. Izingwe is a noun class 10 , izin- is a prefix of noun class 10 and root stem -ngwe. However, through the use of this clan, the clan name giver appears as a person who experienced or observed Ngwekazi people repeating the same procedure several times and no one disagreed with him because it was a fact. Ngwekazi people were using weapons that they had to defeat enemies in wars, it did not matter how the weapons of enemies were good that is why they say people of Ngwekazi are the leopards that conspicuous by their spots, (Ntshangase, 2015).

Izingwe (noun) + kazi $($ adverb $)=($ Izi)ngwekazi $=$ Ngwekazi $($ compound noun $)$

6.8.2 Mzilikazi (Khumalo) (Widow/Big Place)

The noun uMzili (widow) + kazi (big) are combined to produce the clan name Mzilikazi. UMzili is a noun class 3, um- is a prefix of noun class 3 and root stem -zila. The suffix -kazi are used to indicate the femine sex and the augmentative, (Taljaard and Bosch, 1998:144). In this clan -kazi is used to indicate augmentative. It indicates that the clan name giver saw people of this clan that when killing lot of people in wars, and wives and mothers of those males were becoming widows. However, through the use of this clan, the clan name giver appears as a person who experienced or observed Mzilikazi people repeating the same procedure several times and no one disagreed with him because it was a fact., (Ntshangase, 2015).

Umzili (noun) + kazi $($ adverb $)=(\mathrm{U})$ Mzilikazi $=$ Mzilikazi $($ compound noun $)$

6.9 Clan Names Derived From a Verb and a Verb

A verb phrase is defined as that part of the sentence that indicates the action to be performed.

\subsubsection{Zikalala (Disappear at Night)}

The verb zika (disappear), and a verb lala (sleep) are combined to produce the clan name Zikalala (disappear at night). The other meaning of Zikalala sink down or go out of sight. The verb zika (disappear) plus the verb lala (sleep)) have gone through a phonological process. The clan name giver noticed that people of Zikalala were disappearing at night from one place to another because of wars and then he said you disappear where people are sleeping that is why he gave them this clan.

Zika (verb) + Lala (verb) = Zikalala (compound noun)

\subsubsection{Shabalala (Disappear)}

The verb shaba (be constantly restless), and a verb lala (sleep) are combined to produce the clan name Shabalala (disappear). The verb shaba (be constantly restless) plus the verb lala (sleep)) have gone through a phonological process. The clan name giver noticed that people of Shabalala's enemies were disappearing at night (they were killed by Shabalala people at night), and that is why he gave them this clan.

Shaba $($ verb $)+$ Lala $($ verb $)=$ Shabalala $($ compound noun $)$

\subsubsection{Veletshethe (Manana) (Born Carrying)}

The verb vela (appear), and a verb tshethe (carried) are combined to produce the clan name Veletshethe (born carrying). The other meaning of Veletshethe is appear or come into view carrying the verb vela (born), plus the verb tshethe (carried) have gone through a phonological process. The clan name giver noticed that the male people of Veletshethe were showing that they have power at an early age and the clan name giver said you are born with lot of power.

Vela $($ verb $)+$ tshethe $($ verb $)=$ Veletshethe $($ compound noun)

6.9.4 Khabazela (Mkhize) (Kick Out While Feeling Sleepy),

The verb khaba (kick/kick out), and a verb -zela (feel sleepy) are combined to produce the clan name Khabazela 
(kick out even feeling sleepy). The verb khaba (kick out) plus the verb zela (feel sleepy) have gone through a phonological process. The clan name giver experienced or observed that people of Khabazela were powerful in wars even at night. They were fighting even without even showing that it is a sleeping time, they said to them you kick out even you feel sleepy, from today your clan name is Khabazela.

[Khaba (kick out) (verb)+ zela (feel sleepy) (verb]

\subsection{Clan Names Derived From a Noun and a Noun}

Nkosi et al (1994:120) say the prefix of the noun prefix of the second noun, usually it is deleted.

\subsubsection{Ndabezitha (Matter Discussed by the Enemies) (Zulu And Khumalo)}

The noun indaba (matter) and a noun izitha (enemies) are combined to produce the clan name Ndabezitha (matter discussed by the enemies). Ndabezitha is a name for Zulu royalty and it is used when addressing royalty; your majesty. The indaba (matter) is formed from the class 9 (in- prefix), plus izitha (enemies) is formed from the class 10 (izin- prefix). Indaba and izitha have gone through a phonological process to form Ndabezitha. The clan name giver experienced or noticed that Zulu warriors were not defeated easily and most of their enemies most of the time were discussing plans of defeating them, and then the clan name giver said your enemies are always discussing about you thus from today you are Ndabezitha, (Ntshangase, 2015).

Indaba $($ noun $)+$ izitha $($ noun $)=($ I)ndabaizitha $=$ Ndabezitha $($ compound noun $)$

(a and $\mathrm{i}$ combined to give e).

\subsubsection{Ndabandaba (Many Matters/Many News)}

The noun izindaba (matters) and a noun izindaba (matters) are combined to produce the clan name Ndabandaba (many matters). The izindaba (matters) is formed from the class 10 (izin- prefix) plus izindaba (matters) is formed from the class 10 (izin- prefix). Izindaba and izindaba have gone through a phonological process to form Ndabandaba. The clan name giver experienced or observed that people of Ndabandaba had many matters to discuss and they liked to discuss those matters, and the clan name giver said you are always discussing many matters therefore from today you are Ndabandaba, (Ntshangase, 2015).

Izindaba $($ noun $)+$ izindaba $($ noun $)=($ Izi)ndaba $($ izi $)$ ndaba $=$ Ndabandaba $($ compound noun $)$

(a and $\mathrm{i}$ combined to give e).

\subsection{Clan Names Derived From a Noun and a Pronoun}

According to Nkosi (1994:121) et al all pronouns can be a second part of the compound.

6.11.1 Ntombela (Virgins that are here)

Izintombi (virgins) + ela (here) are combined to produce the clan name Ntombela. Izintombi is a noun class 10 and ezila (demonstrative pronoun). Izin- is a prefix of class noun. It indicates that the clan name giver saw that there were a lot of girls that were beautiful and virgins at Ntombela clan, after seeing that he said there are a lot of virgins here ("Kugcwele izintombi la"). However, through the use of this clan, the clan name giver appears as a person who experienced or noticed that there were a lot of young men that were coming to look for Ntombela's virgins, (Ntshangase, 2015).

Izintombi (virgins) + ezila $($ demonstrative pronoun $)=($ Izi $)$ nto $(z i)$ mbela $=$ Ntombela $($ compound noun $)$

\subsection{Clan Names Derived From a Noun and an Adjective}

Nkosi et al (1994:121) say often the first vowel of the adjective is removed. Many of the compound in this section refer to original noun or relationships.

An adjective is a word category that qualifies a subject or an object in a sentence. According to Ziervogel et al (1987:81) an English adjective qualifies a noun or a pronoun.

\subsubsection{Mthimkhulu (Hadebe) (Long Tree)}

The noun umuthi (tree) and an adjective omkhulu (long) are combined to produce the clan name Mthimkhulu (long tree). The umuthi (tree) is formed from the class 3 (umu- prefix), plus adjective omkhulu (big) is formed from the adjective root stem-khulu (big) and (om- prefix of adjective). Umuthi and omkhulu have gone through a phonological process to form Mthimkhulu. The clan name giver experienced or observed that Mthimkhulu people where they were staying they were lot of long trees and that is why he said they are the people from long trees, (Mzolo, 1977). 
Umuthi (noun) + omkhulu (adjective $)=(\mathrm{U}) \mathrm{m}(\mathrm{u}) \operatorname{th}(\mathrm{i})(\mathrm{o}) \mathrm{mkhulu}=$ Mthimkhulu (compound noun)

6.12.2 Nkabinde (Tall Bull)

The noun izinkabi (bull) and an adjective ezinde (tall) are combined to produce the clan name Nkabinde (tall bull). The izinkabi (bulls) is formed from the class 10 (izin- prefix), plus an adjective ezinde (tall) is formed from the adjective root stem -nde (tall) and (ezi- prefix of adjective). Izinkabi and ezinde have gone through a phonological process to form Nkabinde. The clan name giver experienced or observed that on the cows that Nkabinde people had, there were a lot of tall bulls and that is why they said they are the people of tall bulls.

Inkabi (noun) + ende (adjective)] = Nkabinde (compound noun)

6.12.3 Mashiyamahle (Ngcobo) (Beautiful Eyebrows)

The noun Amashiya (eyebrows) and an adjective amahle (beautiful) are combined to produce the clan name Mashiyamahle (beautiful eyebrows). The amashiya (eyebrows) is formed from the class 6 (ama- prefix), plus an adjective amahle (beautiful) is formed from the adjective root stem -hle (beautiful) and (ama- prefix). Amashiya and amahle have gone through a phonological process to form Mashiyamahle. The clan name giver experienced or observed that there were lot of beautiful virgins with beautiful eyebrows and he said they are the people of Mashiyamahle, (Mzolo, 1977).

Amashiya (noun) + amahle (adjective) $=$ Mashiyamahle (compound noun)

6.12.4 Mabelemade (Manana and Nkabinde) (Long Female Breasts)

The noun amabele (female breasts) and an adjective amade (long) are combined to produce the clan name Mabelemade (long female breasts). The amabele (female breasts) is formed from the class 6 (ama- prefix), plus an adjective amade (long) is formed from the adjective root stem -de (long) and (ama- prefix). Amabele and amade have gone through a phonological process to form Mabelemade. The clan name giver experienced or observed that people of Mabelemade were very helpful to poor people, and he used a simile and said they are like a woman who have long breast and who is feeding many kids.

Amabele (noun) + amade (adjective) $]=$ Mabelemade (compound noun)

\subsection{Clan Name Derived From a Noun and a Relative}

According to Nkosi (1994:122) et al. suggest that here the first vowel of the relative is usually removed.

Most of the times the first vowel of the relative is not included in a compound noun and also some part of the prefix of the noun is removed.

\subsubsection{Nkomzwayo (Cows That Are Able to Hear)}

The noun izinkomo (cows) and an adjective ezwayo (hears) are combined to produce the clan name Nkomzwayo (cows that are able to hear). The izinkomo (cows) is formed from the class 10 (izin- prefix), plus a relative ezwayo (hears) is formed from the relative root stem -zwayo (hears) and (e- prefix). Izinkomo and ezwayo have gone through a phonological process to form Nkomzwayo. The clan name giver experienced or observed that people of Nkomzwayo had lot of cows and multiplied with big number yearly and he said the cows of Nkomzwayo are like people because they listen when they are told to increase.

Izinkomo $($ noun $)+$ ezwayo $($ relative $)=(\operatorname{Izi})$ nkom $(\mathrm{o})+(\mathrm{e}) \mathrm{zwayo}=$ Nkomzwayo $($ compound noun $)$

\section{Conclusion}

Zulu clan names are inherent to the language. In order to understand their meaning, the structure of the different word categories from which they are formed and the cultural background should also be taken into consideration. The Zulu clan naming process cannot be isolated from the context in which these clan names are created: their meanings depend on the context and culture.

This article shows how the meanings in the morphological arrangement of Zulu clan names can carry messages from and experiences of the clan name giver. It has been revealed that many Zulu clan names point to the circumstances of the family at a particular time in their lives.

A study of the morphology of Zulu clan names reveals that the structure of a clan name and its meaning are related, i.e. an example of such a clan name is Khuba (disappoint), which indicates that the clan name giver is disappointed 
about the bad treatment he experienced from the people of Khuba. However, through the use of this clan name, the clan name giver seems good-mannered and no one took exception to this expression, although the message is clear to those who have ill-treated others.

Zulu people use language to expose their experiences, and this is done through the use of words. This means that if there are no words, there can be no sentences and no meaning. Clan names are formed from words, thus clan names, like the language, are the carriers of history of the Zulus. Therefore, it can be concluded by saying that Zulu clan names are rich in meanings.

\section{References}

Babbie, E. (1998). The Practice of Social Research, $8^{\text {th }}$ Edition. Belmont: Wadsworth Publishing Company.

Coates, R. (1999). Word Structure. London: Routledge. https://doi.org/10.4324/9780203255407

Crystal, D. (1991). A Dictionary of Linguistics and Phonetics: user's manual (3 ${ }^{\text {rd }}$ Ed,). Oxford: Blackwell.

Damane, M., \& Sanders, P. B. (1997). Lithoko, Sotho Praise Poems. Clarendon Press, Oxford.

Doke C. M., \& Mofokeng, S. M. (1957). Textbook of Southern Sotho Grammar. London: Longmans. https://doi.org/10.18772/22014057380

Doke, C. M., Malcolm, D. M., Sikakana, J. M. A., \& Vilakazi B. W. (2014). English - isiZulu, isiZulu - English Dictionary. Johannesburg: Wits University Press.

Finnegan, R. (1982). Oral Literature in Africa. London: Oxford University Press.

Fortune, G. (1976). Shona Praise Poetry. Cape Town: University of Cape Town.

Haspelmath, M. (2002). Understanding Morphology. New York: Oxford University Press.

Jousse, M. (1990). The Oral Style: Translated by E. Sienaert and Whitaker. New York and London, Garland Publishing Inc.

Kamera. W. D. (1999). Tinanalelo: Swazi Family Praises. Durban: Center for Oral Studies.

Kaschula, R. H. (1993). Foundations in southern African oral literature, (.eds) Johannesburg: Witwatersrand Press.

Koopman, A. (1984). Zulu Compound Nouns-Towards a Preliminary Analysis. South African Journal of African Languages, 4(1), 94-105. https://doi.org/10.1080/02572117.1984.10586568

Koopman, A. (1990). Some Notes on the Morphology of Zulu Clan Names. South African Journal of African Languages, 10(4), 333-337. https://doi.org/10.1080/02572117.1990.10586866

Kosch, I. M. (1997). Reader for Morphology. Pretoria: University of South Africa.

Kosch, I. M. (2006). Topics in Morphology. Pretoria in African language context: Pretoria: University of South Africa Press.

Kosch, I. M. et al. (2004). Language, Structure and Meaning, Only Study guide for HALLSM-Q. Pretoria: University of South Afrika Press.

Malibe, M. J. (2009). Ubunkondlo Obutholakala Ezithakazelweni ZesiZulu. Unpublished Master of Art. Dissertation. KwaDlangezwa: University of Zululand.

Matthews, P. H. (1991). Morphology, ( $2^{\text {nd }}$ Ed,). Great Britain: Cambridge University Press. https://doi.org/10.1017/CBO9781139166485

Msimang, C. T. (1975). Kusadliwa Ngoludala. Pietemaritzburg: Shuter and Shooter.

Msimang, C. T. (1991). INkosi YiNkosi Ngabantu. Pretoria: Kagiso Publishers.

Mzolo, D. M. (1977). A Study of Nguni Clan Praises in Zululand. Unpublished Master of Arts Dissertation. Pietermaritzburg: University of Natal.

Ndawo, H. M. (1939). lziduko ZamaHlubi. Lovedale Press.

Nida, E. A. (1976). Morphology: The Descriptive Analysis of Words. Michigan: University of Michigan Press.

Nkosi, N. R., \& Msomi, G. N. (1992). Izikhali Zabaqeqeshi Nabafundi. Pietermaritzburg: Reach Out Publishers.

Nkosi, N., Mashumi V. E., Wilkes, A., \& Ntuli, N. S. (1994). IsiZulu Sezikhuthali: Ibanga 8. Pretoria: De jager-Haum. 
Ntshangase, N. N. (2015). Keeping Family History Alive. Pietermaritzburg: University of KwaZulu-Natal.

Okpewho, I. (1992). African Oral Literature. Indianapolis: Indiana University Press.

Ong, W. J. (1982). Orality and Literary: The Technologizing of the Word. London: Routledge. https://doi.org/10.4324/9780203328064

Poulos, G. (1990). A Linguistic Analysis of Venda. Pretoria: Via Afrika Limited.

Poulos, G., \& Msimang, C.T. (1998). A Linguistic Analysis of Zulu. Cape Town: Via Afrika.

Sikhosana, B. R. (1997). A Brief Oral History of Zulu Clans Through Izibongo and Izithakazelo. Unpublished Master of Arts Orality and Literary Studies. Pietermaritzburg: University of Natal.

Sithole, E. T. (1982). Izithakazelo Nezibongo ZakwaZulu, $1^{\text {st }}$ edition. Durban: Marianhill Mission Press.

Spencer, A. (1991). Morphological Theory: An Introduction to Word Structure in Generative Grammar. Oxford: Basil Blackwell Ltd.

Taljaard, P. C., \& Bosch, S. E. (1998). Handbook of IsiZulu. Pretoria: J.L. Van Schaik.

Tsiu, W. M. (2001). Basotho Family Odes (Diboko) and Oral Tradition. Unpublished Master of Arts Dissertation. University of South Africa.

Turner, N. S. (1995). The Significance of Naming in Zulu Society. Unpublished Honours Article. Pietermaritzburg: University of Natal.

Zungu, E. M. (1999). A Comparative Phonological Analysis of the North and Southern Lala Dialects of Tekela Nguni. Unpublished Ph.D. Dissertation. University of South Africa.

Zwane, C. L. (2015). Ucwaningo lwezingathekiso ezitholakala ezithakazelweni zesiZulu. Unpublished Masters dissertation. Pietermaritzburg: University of KwaZulu Natal.

\section{Copyrights}

Copyright for this article is retained by the author(s), with first publication rights granted to the journal.

This is an open-access article distributed under the terms and conditions of the Creative Commons Attribution license (http://creativecommons.org/licenses/by/4.0/). 